\title{
Criminal Adat Law in the Indonesia Criminal Code and the Indonesia Criminal Code Draft
}

\author{
$1^{\text {st }}$ Aris Hardinanto \\ Faculty of Law \\ Universitas Trunojoyo Madura \\ Bangkalan, Indonesia \\ aris@trunojoyo.ac.id
}

\begin{abstract}
Indonesia has a different characteristic compared with those applied in other countries, especially the written text of Law. In general of criminal law, a sentence should base on existing law before crime conducted. Indonesian characteristic in law shows the opposite, customary law specifically. This law has no written text of rule that makes the Criminal Code categorizes it as no legal standing, while in general law there should be certainty in a sentence. This law certainly affects the certainty of general Criminal Code code for the law belongs to customary Criminal Code. The study applies legislation and conceptual approach as well. The code used to analyze the regulation of code related to customary criminal code, while the conceptual is to determine government react toward the existence of customary Criminal Code in Indonesia. The urgent of studying criminal adat law become a serious concern for the government. Criminal Adat law is not clearly written in the Criminal Code, but in fact, custom can be used for a consideration. To accommodate the unique of customary law, the government establishes the Criminal Code Draft code that strictly states the draft of the customary law.
\end{abstract}

Keywords_-criminal; custom; legality;

\section{INTRODUCTION}

Criminal Code is established for not only practical, political and sociological reason but also strictly refer to the frame of National Ideology known as Pancasila. Pancasila can refer to many dimensions. In renewing the criminal code, the basic value of Pancasila should clearly state in each Article along with strategical aspect in the frame of designed coding structure. Therefore, by referring to Pancasila, an individual has already had his right to be a social creature. The concept design team of the Criminal Code has agreed to state that a penalty is used to prevent crime as well as regulating the norm of law in society. By doing this, the government gives a security guarantee to society, gives the criminal a second chance to be a good individual so that he or she can live together in society without any worries of doing next crime and finalizes conflict occurred by the existence of plan statement. Moreover, the action can also recover social balance, bring peace in society and set the guilty free from the convict. The overall punishment theory; general and specific prevention, society protection overview, usage and balance theory that come from the Indonesian custom point of view and even the resocialization theory have already stated inside. Criminal Code must not refer to human act only for punishment does not direct someone to have revenge. Criminal Code must not disobey the aspects related to the individual condition, nature, and local tradition. In this frame, steps taken by the designer team is an affirmation of what is clearly stated in legislation outside of the Criminal Code. These allow the occurrence lex certa principle violation which has been regulated in Article 1 Paragraph 1 of Criminal Code. The appearance violation is admitting enactment of living law that determining someone will go to penal sentence based on customary when legislation does not regulate the specific crime [1].

According to C. Van Vollenhoven, the history of customary (Adat) law discussion in Indonesia has been started since 1783 based on a literary book written and published in London and stored in Sumatra. The book entitled The History of Sumatra in the first and second edition reaches almost four hundred pages while the third consist of almost five hundred pages. The appropriate title for the book is "description" instead of history about Sumatra. A book written by William Marsden explains the term as containing an account of the government, laws, customs, and manners of the native inhabitants". Besides of being the principle of law in a positive value, customary law can be used negatively; specifically, become excussion of doing crime or relieve punishment of crime conducted instead of aggravating it [2]. Based on the legal standing inside national law system, customary law has its own role in enforcing the law.

The research problems of the study are:

1. Does criminal Adat law is explicitly regulated inside Indonesia Criminal Code?

2. Does criminal Adat law is explicitly regulated inside Indonesia Criminal Code Draft?

\section{RESEARCH METHODS}

This article applies the conceptual and legislation approach. Legislation approach is used for analyzing the provisions inside The Criminal Code, while the conceptual 
one is used for explaining a study on criminal adat law formula stated in the Criminal Code Draft.

\section{RESULTS AND DISCUSSION}

\section{A. Legislation Aspect}

Legislation aspect is created by Paul Johan Anselm von Feuerbach (1775- 1833), a scholar of the German Criminal Code who wrote a book entitle Lehrbuch des Peinlichen Recht in 1801. Legislation aspect is formulated in Latin, therefore an assumption of having a close relationship with Ancient Rome is possible. According to Moeljatno, the adagium or even legislation aspect is not exist in Ancient Rome Legal. The first condition to punish someone for doing a crime is the existing of legal that determine an action is considered a crime and should be punished. As an example; a husband persecutes or threats his wife to have sexual intercourse. This action is not considered as a crime according to the Indonesia Criminal Code. Article 285 of the Criminal Code regulates only if the convict and victim are outside marriage status. Dutch female movement insists violence inside marriage to be considered as a crime in order to punish the perpetrator. In the future, legislation determiner will always face this type of conflict. Legislation aspect requires an existing judge in legislation. Beside the Criminal Code content explained before, the formal formulation also requires the action is conducted based on legislation regulated as well. It is stated in Article 3 of the Criminal Procedure Code along with Article 1 paragraph 1 of the Criminal Code that refers to legislation aspects. Therefore, concerning criminal provisions based on Article 1 paragraph 1 of the Indonesia Criminal Code and Article 3 Criminal Procedure Code are a necessity.

Legislation aspect, in general, is strictly different from those in the penal act. In a penal act, an attorney must demand a punishment to perpetrators whose evidence is proven. Legislation aspect relies on the aspect of individualism/ liberalism that refers to giving protection guarantee to someone in the possibility of suffering arbitrary violence conducted by Government. In a totalitarian state, this aspect has been abandoned. USSR eliminates legislation aspects in 1926 but reinstated in 1958. The regime of National Socialist Party has allowed the use of analogy inside the German Criminal Code, although the provisions are eliminated in 1945 at last. Nowadays, legislation aspect has been accepted as essential aspect inside the Criminal Code. The consequence of written penal code is first, an action that is not categorized as a crime according to penal code must not be sentenced. Secondly, the Criminal Code must far from analogical interpretation. Based on the basic concept stated above, legislation aspect consists of 2 primary understanding; conducting a sentence must refer to written existing legal and analogical ignorance.

The analogy is applying a provision to an action that similar to it [3]. Article 1 of the Criminal Code determines the action cannot be sentenced unless there is a legislation regulates it before. Determining of sentence may be happened through legislation informal view or based on the affection of legislation in the content view. In several cases, the judges use an analogy in deciding cases [4] The second focus means the application of legislation based on analogy refers to a determination on a case outside both understandings.

Application based on analogy and sentence determining on undoubted condition deserve to sentence as long as the penal act has taken place. During German occupation in Dutch, the concept was applied for several years by imitating to German in which regime of Nazi uses Gesundes Volksempfinden as the criteria. In 1945, the concept come to end. The function of protecting, determining based on analogical and the Criminal Code cannot run side by side. The Criminal Code strictly regulates actions that are considered a crime. The function of protecting determine a sentence to actions considered morality, not crime. The formal legislation is still well maintained by some states, including Indonesia. The unstated law is also called Adat or customary law. It means all unstated provisions that people obey are legally and formally regulated as long as in line with the basic principle Constitution of Indonesia Year 1945.

\section{B. Formulation of Criminal Adat Law in the Indonesia Criminal Code and the Indonesia Criminal Code Draft}

Beside the existing of criminal Adat law, the Indonesia Criminal Code principles show some articles the reference to the determined custom that clearly states as unwritten law. Such as Article 494 of the Indonesia Criminal Code that states, "sentence to a maximum fine of .... to one who does not deliver sufficient explanation and signs according to social custom ....". Article 302 of Indonesia Criminal Code procedures use a term of "to inappropriate purposes". The explanation for this specific term should find the correct word and suit to custom applied. Those to the example of articles in the Indonesia Criminal Code give the entrance of "customary law" as reasons for sentencing in material form with positive function. According to Masruchin Rubai and Made Sadhi Astuti Djazuli, the application of criminal Adat law is stated in Law of Emergency Situation. This article determines that a formal Indonesia Criminal Code system recognizes written criminal law in Article 1 the Indonesia Criminal Code as well, and unwritten one along with that [5]. Applied regulation living in society, habits and local wisdom are shut down by formal law in the purpose of conditioning the Criminal Code as the only reference for sentencing in society.

The condition of legislation aspect nowadays creates a narrow-minded among the enforcement. They tend to refer only to formal legislation and disobey the living law inside society. One example of the case is Zina (fornication). Zina means doing a sexual activity outside legal marriage. The formal penal code in Indonesia regulates the case in the narrow scope. It describes the act is considered a crime when one or both are bounded in legal marital status. Zina is defined as broad meaning inside society. The justice will fail to find a place in society when Zina cannot be sentenced for formal code does not accommodate.

An effort of renewing the content of the penal code, especially to reformulate the legislation aspect in Indonesia, 
starts from the redesigning the Indonesia Criminal Code Draft. The effort marked by the making of legislation aspect draft. Formally, the draft inside Indonesia Criminal Code design is made by Lembaga Pembinaan Hukum Nasional (National Law Development Agency), especially the Criminal Code Draft Design Book 1 Section. Previously, in Persatuan Sarjana Hukum Indonesia (PERSAHI) congress, Moeljatno states his opinion toward the draft but no respond afterward [6].

The formulas of legislation aspect inside the draft made by LPHN are shown below:

\section{Article 1}

1. No act shall be punished and treated except under the penal provisions of laws already in existence prior to their commission,

2. If there have been amendments in the law since the offense was committed, then the provision applied to the offender shall bet the one that is most favorable to him

\section{Article 2}

1. The determination of whether or not a criminal offense has been committed shall not use an analogy

2. The provision contained in section (1) shall not reduce the enforceability of a living law to the effect that under local tradition an act should be punishable and such act is not found in these laws and regulations [7].

The inclusion of formal written law and Adat law are the implementation of National Legislation Seminar since 1963. The Indonesian legislation characteristic is not similar to those applied in western countries. The differences of law itself caused by the existence of the unwritten law, known as regulation existed in society in form of custom and habit for specific society or community that has transformed to be customary law. Efforts to put material legislation aspect in line with the formal is stated in the draft as the consequence of accommodating unwritten law. The incoming of formula describes that Indonesian people dislike the too formal and separate way of thought.

Indonesia Criminal Code Draft consists of criminal Adat law formula in the determination of Article 1 and literally Article 2 [8]. In the formula of the draft, the expository section describes the importance of inserting living law in society as bellow: the newest draft admits the sentence of the act based on living law which is known as customary law with the purpose to accommodate the sense of justice among people in society. The fact shows that there are always communities and societies across this nation of which unwritten law demand sentences for violation. In this case, judge possible to set a penalty in form of custom obligation that must be obeyed by the convict. These mean that norm, value, and standard inside society demanded to be full filled to reach the sense of justice. The condition will not threaten the application of legal penal, but support the formal in the opposite. There are two problems with the formulation, first, this provision runs counter to the legality principle. It opens possibilities for the police and the judicial authorities to unduly exert their powers on citizens by falsely accusing them of having violated Adat; and the second is the provision would violate the principle of equality for the law if a member of one Adat community could be punished for conduct that would not be punishable if committed by members of other Adat communities. There is a way to fix this problem, criminal courts may only apply Adat crime norms when adjudicating a common statutory crime committed in direct concurrence with an Adat violation, without exceeding, however, the statutory sentencing maximum carried by that common crime. Adat violations not committed in direct concurrence with a statutory crime should then be left to the competence of the civil courts. If an option is considered acceptable, the relevant provision in the Criminal Code Draft could probably be rephrased as follows: violation of unwritten Adat law or Adat crime committed in direct connection with a statutory offense may be taken in account in the regular sentence for the statutory offense. Refer to former explanation stated before, the purpose of inserting unwritten law is to accommodate the law exists in society so that the sense of justice will be fulfilled. One of many solutions to redesign the stiffness of penal code is inserting unwritten law in the procedures for a sense of justice accommodation only.

The development of the Criminal Code in other countries, such as New Sudan, is possible by formulate them in the formal legislation aspect. The New Sudan Criminal Code that state:

Section 3

Punishment of Offences Committed within the New Sudan:

(1) Every person shall be liable to punishment under this Code for every act or omission done within the New Sudan contrary to its provisions.

(2) In the application of this Code, courts may consider the existing customary laws and practice prevailing in each area.

The Sudan New Criminal Code states that one is sentenced because of committing crime in purpose or not based on applied code before (formal legislation), in the other hand the paragraph 2, people principle and customs become judge consideration in deciding legal matters (material legislation). Therefore, reorientation of legislation aspect in criminal code is clearly needed as one of many ways to break the stiffness of Indonesia Criminal Code considering that Indonesian people have already had their own customs and local wisdom since ancient time. Moreover, a stigma that a law must set in written form is changing nowadays. Another fundamental aspect is criminal Adat law which belongs to customs law. It is another type of law conducted by people in a specific society and it exists until today [9]. Considering the fact, the existence of custom law and the enforcement along with should be admitted.

\section{CONCLUSION}

1. Criminal Adat law is explicitly unstated in general provision of Indonesia Criminal Code, but in some offenses still, accommodate the living law in form of a custom. 
2. Criminal Adat law in Indonesia Criminal Code Draft is explicitly admitted in the general provisions of Book I Penal Code Draft, that is why the next legislation aspect is not only in formal principle but also material.

\section{ACKNOWLEDGMENT}

The research was done with fund support from Faculty of Law, Universitas Trunojoyo Madura.

\section{REFERENCES}

[1] I. Government, Law Number 1 Year 1951 on Sate of Eemergency. 1951.

[2] C. Van Vollenhoven, Penemuan Hukum Adat. Jakarta: Djambatan, 1987.

[3] H. Vocational, P. Science, and H. Hainan, "Research on Extensive Interpretation and Analogical Interpretation of Criminal Law Wenchao Li," no. SSEHR, pp. 497-501, 2016.
[4] A. Hardinanto, "Manfaat Analogi Dalam Hukum Pidana Untuk Mengatasi Kejahatan yang Mengalami Modernisasi," vol. 31, no. 2, pp. 220-240, 2016.

[5] M. Rubai, Hukum Pidana 1. Malang: Jurusan Hukum Pidana Fakultas Hukum Universitas Brawijaya, 1986.

[6] Sudarto, Hukum Pidana dan Perkembangan Masyarakat. Bandung: Sinar Baru, 1983.

[7] Criminal Law Team Book 1, Penal Code Draft May 2018 Version. National Law Development Agency, 2018.

[8] Criminal Law Section, Penal Code Draft LPHN Version. Jakarta: National Law Development Agency.

[9] I. Susanti and T. Sebastian, "Supremacy of Ethic : National Law , Customary Law and Islamic Law Collided," vol. 84, no. 1, pp. 116-119, 2017. 